PREPARED IN COOPERATION WITH THE

STATE OF CONNECTICUT

GEOLOGICAL AND NATURAL HISTORY SURVEY

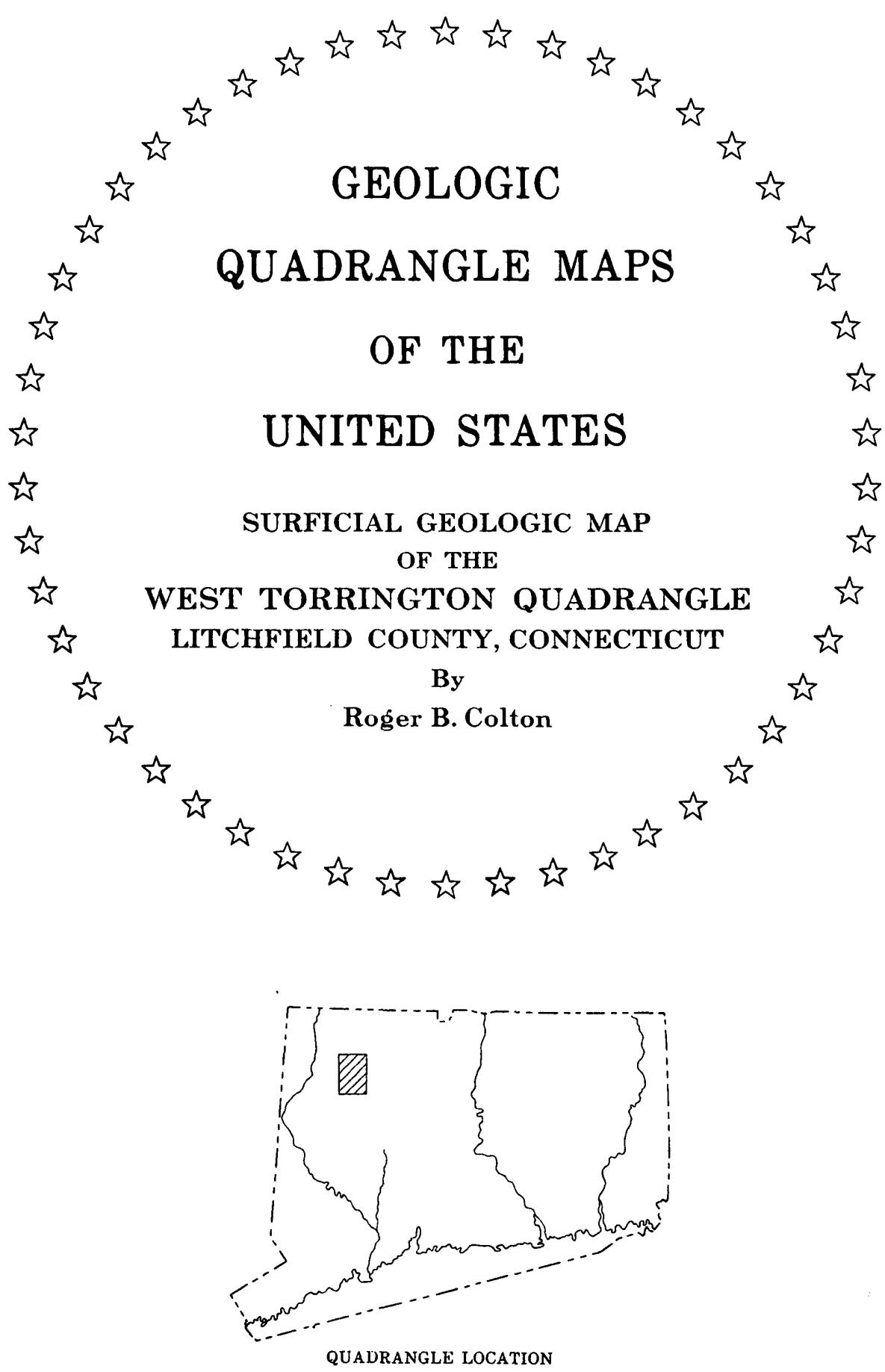




\title{
SURFICIAL GEOLOGIC MAP OF THE WEST TORRINGTON QUADRANGLE LITCHFIELD COUNTY, CONNECTICUT
}

\author{
By Roger B. Colton
}

\section{INTRODUCTION}

The surficial deposits in the West Torrington quadrangle include all unconsolidated materials that overlie bedrock. Most of the surficial deposits are the result of continental glaciation during the Pleistocene Epoch. Other surficial deposits are the products of postglacial geologic processes or are the work of man.

The West Torrington quadrangle, part of the western Connecticut upland, is an irregular hilly area having an average relief between 150 and 250 feet. The maximum local relief is in the northwest part of the quadrangle where Brass and Ivy Mountains stand 300 to 350 feet above the surrounding terrain and also along the valley of the Naugatuck River where there is as much as 600 feet of local relief. The total relief in the quadrangle is 1,080 feet.

The preglacial topography, formed by subaeria 1 erosion in post-Triassic time, was only different in detail from the present surface. Major features such as Brass and Ivy Mountains and the valley of the West Branch of the Naugatuck River show little change.

\section{GLACIATION}

During the Pleistocene Epoch, continental glaciers flowed southeastward across the area as far as Long Island (Flint, 1957, p. 321); Connecticut was probably glaciated several times but evidence for two glaciations was found in two borrow pits in the southeast part of the West Torrington quadrangle. Slight modification of the deposits, the glacial landforms, and the eroded bedrock surfaces in postglacial time suggest that the latest of these glaciations was Wisconsin in age.

Glacial striations were observed at 25 outcrops. Their trend ranges from N. $10^{\circ} \mathrm{W}$, to N. $45^{\circ} \mathrm{W}$.; the average is about $\mathrm{N}^{\circ} 20^{\circ} \mathrm{W}$., roughly parallel to the long axes of drumlins. The striations range in size from hairline scratches to large grooves as much as 2 feet deep, 12 feet wide, and more than 100 feet long. The large grooves were observed half a mile east of Wrightville at an altitude of 1,110 feet above sea level. The trend of these striae and grooves indicates that the ice moved south-southeast across the quadrangle.

The West Torrington quadrangle is characterized by a pronounced south-southeast alinement of long nar row hills, long narrow swamps, and drainage. The trend resulted from a general flow of $\mathrm{glac}$ i a 1 ice $\mathrm{S} .20^{\circ}$ to $25^{\circ}$ E. Glacial till was deposited as long narrow streamlined hills to form drumlins, and as accumulations against bedrock hills or in the lee of such obstacles to produce the crag and tail deposits described by Flint (1957, p. 66). Examples of these drumlinoidal till accumulations against a bedrock knob are 0.65 mile southwest of Junior Republic of Connecticut, 0.8 mile southwest of Newberry Corner, and 1.1 miles east of St. Louis de Montfort Seminary. Drumlinoidal till deposits in the lee of bedrock hills are larger and more prominent. An example is Beech Hill 2.5 miles north-northeast of Goshen. Lucas Hill one mile northeast of Goshen appears to have accumulated in the lee of Ivy Mountain and by erosion on the stoss end and deposition on the tail end may have migrated toward the south-southeast.

Many drumlins have been modified by melt-water streams. For example, Pie Hill 2.0 miles southeast of Goshen has two melt-water channels incised into it; the stoss and lee ends of many other drumlins have been trimmed by melt-water erosion.

However, the long axes of most of the streamlined hills, whether cored with bedrock or not, can be used as indicators of the direction of ice movement. Lucas Hill and hill 1350, 0.7 mile southeast of Goshen (village), are typical drumlins.

\section{GLACIAL DEPOSITS}

Till.--Much of the bedrock surface is covered by a thin mantle of till, locally called "h a r dp a n" or "boulder clay." The till is compact to loose, locally fissile, and light gray (5Y 6/2) (Munsell Color Co., 1954). It ranges in composition from a loose nonfissile sandy gravelly bouldery till to dense, hard, fissile, compact till containing silt and clay in addition to the larger sized particles. Locally. it contains small irregular lenses of contorted, faulted, or sheared stratified sand and gravel. The composition of the till depends almost entirely on the type of bedrock at the source. Areas of schist generally yield a clayey sandy micaceous till, whereas areas underlain by granite yield a sandy gravelly loose till. These till areas extend a mile or two southeast of the respective bedrock outcrop areas.

Two large borrow pits in the southeastern part of the quadrangle exposed tough, dense, dark-gray, fissile, discontinuously stained manganese- and ironstained till overlain by less dense lighter gray till. This lower till is interpreted to be evidence of preWisconsin glaciation, but all other glacial deposits in the quadrangle are believed to be of Wisconsin age.

Till averages about 15 feet thick but is thickest under the crests of the drumlins, especially the larger ones such as Lucas Hill where it is probably as much as 90 feet thick. A well driller's report indicates that the till may be as much as 186 feet thick 1,100 feet north- 
west of the intersection of Pother Hill Road and Brandy: Hill Road. Another report indicates the till may be 115 feet thick 0.1 mile north of the inter'section of Route 4 and East Street North.

Erratics.--Scattered over the quadrangle are numerous glacially transported boulders; many of them are rock types that do not crop out in the quadrangle or for many miles to the north and northwest. The most noticeable are blocks of tremolite marblepresumably carried southeastward from outcrops of the Stockbridge Marble, 8 or more miles to the nor thwest in the township of Canaan (Rodgers and others, 1956). An outstanding example is a block 25 feet long, 20 feet wide, and 15 feet high found on Lucas Hill 1,000 feet north of Route 4 . It is estimated to weigh 63 tons and was transported by the ice at least 8 miles. It is probably underlain by at least 80 feet of till.

Ice-contact stratified deposits.--Ice-contact stratified deposits exhibit a wide range of textures from boulders more than 6 feet in diameter to fine sand and silt. Their surface is commonly hummocky, with closed depressions and irregular ridges indicating collapse of the original deposits after melting of the buried or supporting ice. Fresh exposures in sand and $\mathrm{gr}$ a vel pits and other excavations characteristically show faulted, contorted, and tilted strata.

Because ice-contact stratified drift deposits in the West Torrington quadrangle are small and scattered, they have not been grouped into sequences and correlated. However, the southernmost and highest gravel deposits were formed first; those at lower levels are younger. Thus the northernmost and lowest gravel deposits, those along the West Branch of the Naugatuck River, presumably are the youngest. The coarse outwash deposits in the City of Torrington were deposited by melt water from the valley leading northeast from Torrington to Winsted.

\section{DEGLACIATION}

During deglaciation large masses of stagnant ice occupied positions now indicated by some of the swamp deposits. Glacial melt-water streams eroded numerous ice-marginal channels in till and bedrock and redeposited the materials released from the ice and the eroded till as ice-contact stratified drift.

The large areas of water-worn bedrock in the quadrangle are a puzzling result of the deglaciation of the area. Areas 1 mile north of Goshen, on Brush Hill, 1.7 miles east of Goshen, and 1.5 miles northeast, and 1.5 miles northwest of the For man School in Litchfield are devoid of till or sand and gravel and apparently have been washed clean by glacial melt water. The problem is that most of these areas are not connected with each other or with channel systems, and some are surrounded by till that apparently has not been scoured by melt water. Some are knobs of bedrock that stand above the surrounding till areas but others are below the surrounding till areas. The se areas of water -worn bedrock could have been caused by large volumes of melt water that swiftly flowed on, in, or under stagnant ice and almost at random eroded the till and bedrock surface for short distances and then flowed on the ice again. There probably were several simultaneous melt-water streams which undoubtedly shifted their courses rapidly and widely.

One well-developed melt-water channel is 1,000 feet west of Town Farm Road in Litchfield and begins
1,200 feet south of the Torrington-Litchfield town line. The channel is about half a mile long and 100 to 200 feet wide. The altitude of the floor of the channel is at 1,200 feet at its north end and the floor rises southward 20 to 25 feet for 800 feet. Then the floor of the channel slopes southward 10 to 15 feet in 700 feet to a cowpath. South of this cowpath leading west from the former town farm, the altitude of the channel floor decreases 100 feet in a distance of 1,400 feet. The fact that the floor of this channel rises and falls along the long profile suggests that the melt water which eroded it was probably flowing in a subglacial tunnel under hydrostatic pressure. A field check of the feature suggested that little postglacial erosion occurred in the north half of the channel and only slight deepening occurred in the south half.

\section{LAKE DEPOSITS}

Several small temporary lakes formed in the quadrangle as deglaciation occurred. Lake deposits have not been mapped because all are too thin, except where overlain by swamp deposits. The largest was south and southwest of Besse Hill. Test borings made by the Connecticut State Highway Department along Route 25 where it crosses the headwaters of Gulf Stream indicate that as much as 38 feet of fine gravelly sand, silt, clay, and fine gravel underlies the large flat, swampy area. The spillway at the southwest end of the temporary lake is at an altitude of 900 feet. Presumably the lake was drained when Gulf Stream breached a former drainage divide (just south of Newberry Corner) through a process of slow headward erosion. Probably the hill just east of Newberry Cor ner extended southward to the next hill, and the low point on the divide was slightly more than 900 feet above sea level.

Another small lake may have existed for a short time near the center of the quadrangle in the area traversed by the Bantam River just east of Pie Hill. The present topography and distribution of surficial deposits suggest that a temporary lake may have risen to an altitude of 1,120 feet. It probably overflowed across a till or ice dam 0.2 mile east of the intersection of Norfolk Road and Weed Road. The lake was drained when the overflow water cut down through the dam of till or ice.

A small temporary lake may have occupied the valley 0.5 mile south of the Torrington Country Club ( 1 mile east of Goshen village). It may have been held in by the retreating ice or by a dam of till at an altitude of 1,190 feet 0.3 mile northeast of the Litchfield Reservoir. This lake probably was drained when the overflow water cut down through the barrier of drift or when the dam of ice melted.

A larger lake may have covered the area around Dog Pond and may have had a maximum altitude of 1,250 feet. South of Dog Pond the present topography suggests that the lake overflowed to the south through a wind gap at 1,250 feet altitude before it was drained through the water gap just north of Town Hill.'

A temporary lake may have existed in the valley southwest of Brush Hill at an altitude of 1,160 feet. Present topography suggests that it spilled over through a channel 0.4 mile west of Junior Republic of Connecticut. The lake was probably held in by ice or by a low ridge of till at the site of the present out let 0.4 mile west of the intersection of Route 63 and 
Deming Road.

Present topography suggests that a till dam 0.3 mile north of the Forman School in Litchfield held back a lake at an altitude of 1,090 feet. The lake may have been held in by ice along the east side (along Norfolk Road) and may have spilled over at an altitude of 1,090 feet through the channel 0.6 mile southwest of Junior Republic of Connecticut.

\section{POSTGLACIAL DEPOSITS}

Early postglacial time was characterized by the return of forest vegetation, by soil formation, and by the development of swamps in many of the closed depressions. Streams dissected the glacial deposits. Streams eroding headward dumped fan-shaped deposits of gravel at junctions with major valleys. Narrow bodies of alluvium now occupy most of the broader valley bottoms. A talus deposit 1,100 feet long, 50 feet wide, and 80 feet high formed at the southwest end of Brass Mountain.

Swamp deposits.--Many small ponds probably existed in areas now occupied by swamp deposits. Initially each of these temporary ponds may have held a block of stagnant ice. The ponds were gradually filled, mostly with organic sediment, during postglacial time and now consist of dark-brown to black muck and peat. Thickness of the deposits ranges from 0 at the edge to 25 feet.

Eolian deposits.--Most of the glacial deposits are covered by a thin discontinuous veneer of unstratified yellowish-brown silt and sand that averages 2 feet thick and is locally as much as 5 feet thick (not mapped). This mantle of eolian silt and sand is thin or absent on hilltops and in parts of valley floors is overlain by recent younger alluvial deposits. Locally it is thick along valley sides where it may also be mixed with the extensive thin blanket of colluvium (also not mapped).

The eolian deposits consist of fine sand and siltsized particles with scattered coarser sand and pebbles. In some places these deposits contain cobbles and boulders which apparently have come from underlying till or gravel as a result of frost heaving, solifluction, and tree throw such as occurred extensively during the September 1938 hurricane. The deposit is loose, permeable, and oxidized to grayish orange to light brown near the surface.

Alluvium.--Stream deposits consisting of light-gray or yellowish-gray clay, silt, sand, and gravel, but mostly bouldery gravel, are along the East and West Branches of the Naugatuck River, the Bantam River, and many small tributary streams. These long narrow bodies of gravel and finer materials are generally 5 to 10 feet thick; they thin toward each side of the deposit. Coarse outwash gravels probably underlie the alluvium and may be included in the areas mapped as alluvium. Many small narrow bodies of alluvium have not been mapped.
Landslide deposits.--A few small landslide areas are found along the Bantam River 1.2 miles north of the Forman School in Litchfield. One other small area is 1,000 feet north of Route 25 and 2,300 feet east of Town Farm Road. The areas involved are only a few hundred feet long and extend less than 100 feet back from the stream. The undercut banks are as much as 80 feet high.

Artificial fill.--Artificial fill in highways, railroad embankments, and small dams consists of till, sand, gravel, and crushed rock. The largest artificial fills in the quadrangle are the two large rock-fill floodcontrol dams about 4 miles northwest of Torrington; they are as much as 60 feet thick. Numerous small trash fills (dumps) have not been mapped.

\section{ECONOMIC GEOLOGY}

The most valuable natural resources in the quadrangle are sand and gravel in the ice-contact stratified drift deposits. Unfortunately, the gravel deposits are small and composed of poorly sorted and stratified coarse gravel. Most of them have been exploited and some are nearly depleted.

The swamps have served as sources of peat, but as the utilization of peat in this quadrangle is limited, these deposits are of minor economic importance. If the swamps were drained, cleared, and tilled, they would provide small areas of rich soil for specialized agricultural uses.

Till has been used extensively for fill along Routes 25 and 116 and is probably better for this purpose than sand and gravel.

There are a few small abandoned quarries in granite within a mile of West Torrington. An abandoned soapstone quarry 250 feet long and 50 to 10 . feet wide is 0.5 mile north of Soapstone Hill Road in the center of the quadrangle. An attempt was made to mine nickel 0.85 mile west-northwest of Wrightville. More information on these quarries can be obtained from Gates and Christensen (1965).

\section{REFERENCES CITED}

Flint, R. F., 1957, Glacial and Pleistocene geology: New York, John Wiley \& Sons, $553 \mathrm{p}$.

Gates, R. M., and Christensen, N. I., 1965, The bedrock geology of the West Torrington quadrangle: Connecticut Geol. Nat. History Survey Quad. Rept. $17,38 \mathrm{p}$.

Munsell Color Company, 1954, Munsell soil color chart: Baltimore, Md., Munsell Color Co., Inc.

Rodgers, John, Cameron, E. N., Gates, R. M., and Ross, R. J., Jr., 1956, Preliminary geological map of Connecticut: Connecticut Geol. Nat. History Sur vey. 